\title{
Inequality and Criminality Revisited: further evidence from Brazil
}

\section{Autores:}

1. Maria Bernadete Sarmiento Gutierrez. (autor principal)

OECD - Organization for Economic Co-operation and Development

IPEA - Instituto de Pesquisa Econômica Aplicada

UFF - Universidade Federal Fluminense, Depto de Economia.,

Email:masmig@uol.com.br

2. Mario Jorge Cardoso de Mendonça (autor para correspondência)

IPEA - Instituto de Pesquisa Econômica Aplicada

Avenida Presidente Antônio Carlos, 51 sala 1414.

Centro, Rio de Janeiro, RJ CEP: 20020-010, Brasil

Tel. (55) (21) 38048067

Fax ( 55 ) (21) 22241920

Email: mjorge@ipea.gov.br, mjorgecm@hotmail.com

\section{Adolfo Sachsida}

Universidade Católica de Brasília

Department of Economics

Email: sachsida@pos.ucb.br

4. Paulo Roberto Amorim Loureiro.

Universidade Católica de Brasília

Departement of Economics

Email:paulol@pos.ucb.br 
Abstract: The objective of this study is to shed light on the determinants of criminality in Brazil. In order to undertake it we performed an econometric model based in panel data analysis for Brazilian states: Among the major conclusions we have an important result that income inequality plays an important role in criminality. Results also showed that unemployment and urbanization are positively related to crime factors. Based in panel data GMM methodology we found the existence of "inertial effect" on criminality. Panel data GMM estimator was also used to control the existence of endogeneity related to the variable public security. In this case, the results showed that public security spending is effective to diminishes criminality. Contrary to the common wisdom, we cannot found evidence that poverty increases violent crime. Finally considering the results from the Granger causality tests, it was possible to show that inequality causes crime in fact and not the contrary, what supports that the income inequality in an inequivocous determinant of criminality.

Key Words: Criminality, inequality, panel data model, GMM estimator and Granger causality.

JEL: K42, C23, Z13

ANPEC: Área 6.

Resumo: O objetivo deste trabalho é de lançar luz sobre os fatores determinantes da criminalidade no Brazil. Com o fim de levar a cabo esta tarefa, estima-se um modelo econométrico usando dados de panel para os diferentes estados brasileiros. Uma das conclusões mais importantes que emerge desta análise é que a desigualdade de renda desempenha um papel fundamental na determinação da criminalidade. Os resultados também mostram que o desemprego e a grau de urbanização estão relacionados de forma positiva com a criminalidade. Pela análise dos resultados usando a metodologia GMM, constatamos a existência do efeito "inércia" sobre a criminalidade. Por outro lado, esta mesma metodologia foi usada para controlar o efeito da endogeneidade da variável segurança pública. Neste caso, os resultados mostram que os gastos de segurança pública são capazes de diminuir a criminalidade. Contrariamente à visão tradicional, não foi detectada a relação que a pobreza afeta o crime violento de forma positiva. Finalmente, com base nos testes de causalidade de Granger, foi possível mostar que a desigualdade é causa do crime, mas não a relação inversa, compatível com o fato que a desiguldade de renda é um determinante inequívoco da criminalidade.

Palavras-chave: Criminalidade, desigualdade, dados em panel, estimador GMM, causalidade de Granger. 


\title{
INEQUALITY AND CRIMINALITY: FURTHER EVIDENCE FROM BRAZIL
}

\author{
Maria Bernadete Sarmiento Gutierrez. (autor principal) \\ OECD - Organization for Economic Co-operation and Development \\ IPEA - Instituto de Pesquisa Econômica Aplicada \\ UFF - Universidade Federal Fluminense, Depto de Economia \\ Mario Jorge Cardoso de Mendonça (autor para correspondência) \\ IPEA - Instituto de Pesquisa Econômica Aplicada \\ Adolfo Sachsida \\ Universidade Católica de Brasília - Department of Economics \\ Paulo Roberto Amorim Loureiro \\ Universidade Católica de Brasília - Departement of Economics
}

\section{Introduction.}

This study aims at shedding light on the main determining factors motivating criminal activity in Brazil. A first sight analysis of recently released data shows that for the country as a whole recent growth rates of criminality have been impressively high, not only in levels but also at recent the rates of growth. The average number of homicides jumped from 14.8 to 22.6 per 100,000 inhabitants between the periods 1980-84 and 1990-95, an increase of 52 percent. For the state with the highest income per capita in the country, Distrito Federal, homicides increased from 14.3 to 33.7 per 100,000 inhabitants between the same two periods, a growth rate of 135 percent. Andrade and Lisboa (2000) show that, in the state of São Paulo, the number of homicides per 100,000 inhabitants jumped from 54.4 in 1981 to 128.4 in 1995 among young men between the ages of 15 and 24, and from 49.3 to 106.2 for men between 25 and 44 years of age. These are increases of $136 \%$ and $115 \%$, respectively. In the state of Rio de Janeiro, for men between the ages of 15 and 24, the specific homicide rate increases $85 \%$ in the same period.

In a seminal paper, Becker (1968) framed criminality in an economic context as an agent's behavior dealing with risk. In this case, the agent compares how much he can earn in the labor market without risk with the expected income from an illegal activity. Therefore, Becker (1968) focuses on the effect of the relationship between the return and the risk of a criminal act has on criminality rates. However, the analysis of this issue from a strictly financial standpoint may lead us to underestimate the problem, by incompletely identifying the mechanisms through which criminality operates. In certain contexts, it is possible to verify a continuous growth in criminal activity along with a extremely severe law enforcement state and unattractive returns.

For instance, a situation described by Levitt and Venkatesh (1996) is a good example of this. In their study, the authors show that risk of death or imprisonment is much higher among lower status members of the gangs in Chicago, income being less the federal minimum wage. The justification found by the authors is the expected social mobility within the organization. However, this argument sounds contradictory. The soldiers's attitude would only be justified if there were a higher turnover rate in the upper strata of crime. If this is the case, it is because the higher status members end being eliminated in the short to mid term. Nevertheless, this does not sound reasonable, for there would be a reduction in the discounted utility, that would in turn not reduce the pay-off resulting from the decision to participate in said market.

Toward this objective, we shall argue along slightly wider lines than those followed by Becker (1968), like others studies, introducing new elements to our analysis. We do consider that the relation between return and risk is very relevant in explaining criminality; however we do point out the existence of other factors that contribute to the evolution of the phenomenon like social determinants, emphasizing the adverse effect that social inequality exerts upon criminality. According to the IBGE ${ }^{1}$, in 1998, Brazil's richest 1 percent controlled 14 percent of the nation's wealth. This amount was larger than the amount controlled by the poorest 50 percent of the population. Furthermore, the bottom 40

\footnotetext{
${ }^{1}$ Brazilian Institute of Geography and Statistics.
} 
percent of the population earned on average 20 times less than the top 10 percent. Not surprisingly, in 1998 Brazil had one of the highest Gini coefficients in the world, appearing in $148^{\text {th }}$ place in an ascending list of 150 national Gini coefficients.

Kelly (2000) shows that, for violent crime, the impact of inequality is large, although it has no effect on the property crime. For the Brazilian case, Mendonça, Loureiro and Sachsida (2002) based in earliest studies [Grogger (1997); Witte and Witt (2000); Imai and Krishna (2001); Lochner (2001); inter alia] have also shown that violent crimes (such as homicide and rape) are more related to factors like social interaction, family heritage and family instability variables than non-violent crimes (such as theft).

The fundamental aim of this study is to estimate an econometric model of criminality for Brazil based in agregated data by states from 1981 to 1995. Specifically, our econometric analysis will focus on the determinants of intentional homicides. This study is structured as follows. Section 2 provides the background found in the literature in which the relationship between inequality and criminality is discussed. In Section 3, we shed light on the main variables considered related to the phenomenon of criminality. In this section, we will also select variables that will be tested in our econometric analysis exercise. The database is presented in Section 4. Next in Section 5, we develop an econometric analysis for the Brazilian case. This section is composed of two parts. In the first one, we develop an econometric model of criminatity based on extensive analysis involving panel data. Futher analysis applying GMM panel data estimator is used in order to control endogeneity between crime and public security spending. In the second one we also use econometric methods in order to implement Granger causality's approach to find the true causality relations between criminality and variables like income inequality and spending in public security. Lastly, in Section 5, the study's main conclusions are presented.

\section{Inequality and Criminality: Background}

The relationship between crime and inequality has been studied for a long time in the literature. Similar versions of our proposal have appeared in some sociological theories. Merton's (1938) strain theory and Hagan and Petersen (1995) argue that the frustration felt by lower income individuals when perceiving the prosperity of others, also called "relative privation", may explain the effect inequality has on criminality. Some studies also point out, in a more specific sense, that poverty is a factor that influences criminality. The argument here is that the social disorganization generated by poverty reduces the informal control mechanisms acting upon the individual, resulting in an increase in criminality (Hagan and Petersen, 1995). Kennedy et al (1998) hypothesized that the effect of the growing gap between the rich and the poor people is mediated through an undermining of social cohesion, or social capital, and that decreased social capital is in turn associated with increased firearm homicide and violent crime. This is also related to the social disorganization theory that argues that crime happens when the social mechanisms supporting society, like a community's ability to regulate its member, are weakened. The influential study of Blau and Blau (1982) found a strong relationship between income inequality and homicide rate. Daly, Wilson and Vasdev (2001) also support the proposition that the degree to which resources are unequally distributed is a stronger determinant of levels of lethal violence in modern nation states than is the average level of material welfare.

The economic literature on crime suggests that inequality can generate criminality. But how inequality causes crime under economic views? There is a vast literature of theories pointing out the exact economic mechanisms governing inequality and crime. First, based in the earliest works of Becker (1968) and Ehrlich (1973), individuals can allocate time between market and illegal activities by comparing the expected return from these alternatives. Inequality creates crime by placing low-income individuals who have low returns in the labor market next to high-income individuals. This proximity contributes to a frustration feeling, or 
"envy effect", already mentioned before, becoming an important determining factor in criminality. This idea appeared in a more concise economic framework in Eastherlin's seminal work in 1980. In this study, Eastherlin (1980) trys to explain why people in the US, Japan, continental Europe or Britain have not become happier, in despite of the strong economic growth. One possible reason for this, in line with a major finding from happiness surveys, is that satisfaction/ happiness depends on some "status ranking", that is, it matters not only the absolute economic well-being but also its relative position in society.

Third, one similar theory is based on the idea that agents have a targeted consumption, by which inequality exerts a positive impact on criminality. It is reasonable to state that this targeted consumption tends to reach those levels of satisfaction experienced by richer agents. It may be argued here that targeted consumption arises from close contact among groups for whom the dispersion of wealth is great, or further, it would be valid to state that mass communication establishes certain standards that could be considered references. Bearing this in mind, the agent derives dissatisfaction from the difference between the level of targeted consumption and the level of consumption that may in fact be obtained with his/her income. Dissatisfaction reduces utility, by making the agent perceive his/her income as being "lower", thus reducing the discounted value of her/his utility. It is fair to assume that an increase in the targeted income makes the agent demand a higher remuneration to participate in the labor market. Thus, there must be a direct relation between income inequality and criminality. A high level of inequality implies a high level of dissatisfaction and, as will be shown, there is also a relation between dissatisfaction and the required income to stay out of criminality. Considering the stance taken here, poverty by itself is not considered a direct factor leading to criminality but only an indirect one. The analysis must then focus on poorer individuals' perception of their relative deprivation when comparing with higher income status groups.

Finally, we can find more specific economic channels by which social inequality is related to criminality if one assumes that illegal activities also depend on economic growth. Firstly, inequality manisfests itself through capital market imperfections since the poor are deprived of the efficient resources to investment. Secondly, inequality influences the balance of power in the political system in such a way to generate pressures to government increase income distribution that, in turn, slows the incentives to work and, thereby, slows down economic growth. Finally, there is an ancient argument that inequality contributes to deviate behavior and non-compliance to social norms, therefore reducing the security of norms and property rights which, in their turn, discourages investment and economic growth [Persson and Tabellini, (1998), Bénabou, (1996), Aghion and Howitt, (1998)].

We just highlighted the channels through which inequality causes crime, but can criminality generate inequality too? There are at least four arguments to explain the channels through which violence generates income inequality: a) Violent areas are less atractive to new investments, in this way, violent areas will gradativelly become poor and non violent areas, receiving the investments, will gradativelly become more rich; b) the most skilled people will prefer to work in non violent areas. In this way, the better teachers (for example) will teach in safer places, and the education of the children living in violent areas, will be in charge of the worst teachers. That is, the children of violent areas will receive a less quality study than children who live in non-violent areas. In the long run, this difference in the skills, originated by violence, will generate income inequality; c) the most skilled individuals will prefer to live in non violent areas. On the belief that social interaction (or networks) is important to the future of the children, it is the case that children living in non-violent places will have a better enviroment to their development than the children living in violent places. Again, the difference in the skills of the children, generated by violence, will imply an income inequality in the future; and d) statistical discrimination by which an individual will receive a lower wage, just because she/ he lives in a violent place. For example, two individuals, with the 
same human capital and working in the same area, will receive different wages, just because they live in places with different levels of violence. The idea of the employer is that he does not know the skills of each individual, so he attributes to each one the characteristics of the region of origin. In this way, the difference in the wages will generate income inequality, but the wage differential was originated by violence. We use in this study the Gini coefficient [Kelly (2000), Fajnzylber (2002)] as our measure of income inequality.

\section{Potential Explanatory Variables for Criminality.}

We will describe now in details the other main factors pointed out in the literature that have effects on criminality, as well as the variables selected to represent them in our model. First, in order to designate the independent variable regarding criminality, we shall use the number of intentional homicides as a proxy, normalized in relation to the population of the state, according to other studies [Fajnzylber, 1998]. However, there are some problems regarding the choice of this variable, and at least two points need to be made. First, deaths considered intentional homicides are not always correctly classified, for deaths resulting from wounds are sometimes included in the statistics regardless of whether or not the wounds were intentionally inflicted. A second problem is that some incidents end up not being registered, due to the fact that certain deaths are not reported. This normally takes place more frequently in rural areas as opposed to urban areas. However, as pointed out by Cano \& Santos (2000), the under-registry of deaths due to external causes is much lower than those resulting from natural causes. Also, if the under-registry remains stable over time, it may be controlled with the use of panel data, by applying fixed effects [Fajnzylber \& Araújo, 2001].

In the literature on criminality, several variables are used to explain it. Among them we can mention income, unemployment, schooling, structure of law enforcement, poverty, inequality, urbanization and so on, but it has been difficult for researchers finding the exact channel by which some of them support crime.

Becker (1968) emphasizes that the attitude of an agent, when participating in an illicit activity, is well represented by a situation of choice involving risk. So, the agent ponders the pros and cons of breaking the law by comparing the expected return of this lottery with the income to be obtained from a risk-free activity. In order to represent the return of an agent participating in an illicit activity one can adopt average family income as a proxy for this variable. This procedure was used by Ehrlich (1973). So, upwards shifts in the equilibrium level of income, increases the probability of an agent of engaging in criminal activity. In this case, we find a positive relationship between average income and crime. But one can say too that a positive shift on income increases the agent's oportunity cost to engage in illegal activity. Then we cannot state a priori the expected sign of the average income in its relationship with criminality.

Schooling has been always mentionned in the literature as having important effects on criminality. But, like the same case of income, it is not so easy to determine a priori what kind of correlation there is between crime and schooling. It is said that schooling diminishs crime because it increases the oportunity cost for the agent engaging in illegal activity. Therefore, it could be expected to find a negative correlation between both variables. Yet, more schooling one has, more able one will be to commit crime efficiently. So, in this case, the effect of schooling on criminality is positive. So, we can not state the true impact of schooling on the agent's decision taking part in criminality a priori. Based on the statistics of crime, one know that the majority of cases of criminatity are undertaken by males. So, it is fair to assume that the impact of schooling on criminality is more important to males than females. In this case, we will test in this work the variable schooling for males above fifteen years old. 
The degree of urbanization (the ratio between urban population and total population) also appears as one variable that can explain crime. It is used as a proxy of the cost of entering into crime because there is no explict information about it [Fajnzylber, 1998]. This is justified by the fact that the interaction between groups of criminals and potential criminals would make it easier for the latter to enter the criminality market, since interaction among agents stimulates the exchange of information. We must keep in mind, however, that something more important may be implicit in this variable that would be related to the degree of social interaction among individuals. Social interaction may be defined by including variables that represent other people's characteristics by which would affect an individual's production in the individual's utility function. Thus, we then have the hypothesis that the agent's behavior would be strongly influenced by the group to which he or she belongs [Durlauf, (2001). Glaeser, Sacerdote and Scheinkman, (1996)]. Thus, the rate of urbanization must be positively correlated with criminality.

Some studies indicate the existence of a positive relation between unemployment and criminality [Erlich, (1973), Trumbull, (1989), Gould et al. (1997)]. Freeman (1994) has shown that the negative sign is a recurring result for the first lag of this variable. Thus, the unemployment rate shall also be tested as an explicative variable in the model. The literature points out that unemployment has two distinct effects on criminality. The first, called the opportunity effect, refers to the negative influence that unemployment exerts upon crime due to the decrease in available wealth, because of the lower return from the activity. The second effect is known as criminal motivation. This effect is brought about by a reduction in the agent's income, as well as by the depreciation of human capital due to the period of absence from the labor market. Thus, the longer the agent remains unemployed, the greater the probability of taking part in crime (Erlich, 1973).

Related to the structure of law enforcement, different variables are used in econometric studies on criminality. Some studies introduce the ratio of the number of convictions to the total number of reported incidents to identify the penalty imposed on the agent. [Fajnzylber, 1998]. Another variable that could be used would be the size of each state's police force. Unfortunately, data for these variables are not available for Brazil. But under certain hipotheses and due to the availability of data, we can take the spending on public security as a proxy for these variables. It is expected that criminality, represented by the number of intentional homicides, be negatively correlated with this variable. We must keep in mind, however, that for this variable endogeneity may occur: It is possible that a lower rate of criminality in a given region would have the effect of generating less public law enforcement spending or areas with high incidence of criminality have high rates of police expenditure. Studies that ignore endogeneity usually find that police activity has no impact on crime (Cameron, 1988).

Finaly, poverty measured by the percentage of the population below the poverty line appears in literature among variables used to explain criminality because its positive relation according researchers with social desorganization. In spite of it, Kelly (2000) found inverse correlation between violent crime and poverty although without significance. Table 1 below provides a summary of the variables used in this study.

\section{TABLE 1}

\section{Data Base.}


Information regarding intentional homicides (CID-BR-9) is available for all Brazilian regions. This information is handled by DATASUS, the main data base on population health maintained by the Brazilian Ministry of Health. With regard to the variables average family income, the Gini index, poverty, schooling, unemployment and the rate of urbanization, the data used in this study were obtained from the following databases: i) the series on average family income, male schooling, unemployment and the Gini index were extracted from the PNAD $^{2}$; and ii) the rate of urbanization was obtained from the Demographic Census. Both the PNAD and the Demographic Census were produced by the $\mathrm{IBGE}^{3}$. Information on state law enforcement spending was obtained from the Brazilian Finance Report produced by $\mathrm{NTS}^{4}$. Lastly, the population that will be used to normalize the intentional and homicides was obtained from the Demographic Census produced by IBGE. In the years for which no census was taken, the values were obtained by interpolation.

\section{Econometric Model of Criminality.}

\subsection{A Panel Data Analysis for Brazilian States.}

As the extensive survey of Land, McCall and Cohen (1990) shows empirical results that appear in literature on crime can be biased because of the strong collinearity among measures like inequality, poverty, unemployment and others variables used in econometric models. So, first of all, we have to undertake a study in order to identify collinerity among the variables described in the last Section and choosing a set of regressors in order to separate the effect of each one without bias.

Following Kelly (2000) in Table 2 we present simple correlations for pooling data among potential explanatory variables described in Section 3. A sight inspection of Table 2 shows that there is a core of variables that are strongly correlated: income, schooling and poverty. The reason why income and schooling are correlated is simple. There is a extensive literature on returns on schooling that identifies the unquestionable relationship between income and schooling [Mincer (1958), Becker (1975), Card, (2001), inter allia]. Another important correlation is between income and poverty or schooling and poverty, albeit the last one is more tenous. In fact, after performing a number of OLS regressions and using the VIF $^{5}$ instrument, we have got relevant conclusions. First, we can not run a regression with schooling and income in the same set of regressors. Second, the presence of schooling seems to introduce bias in the coeficient of poverty, although the bias generated in the coeficient of poverty is stronger in the presence of the variable income. Based in these facts and in order to isolate the true impact of each explanatory variable, we decide to not include income in the econometric model and present the results based in two set of variables: one with schooling and poverty in the same set and, another one, in which we exclude schooling in views of the existence of multicolinearity existing between these two explantory variables.

\section{TABLE 2}

To estimate the crime model as described in the previous sections, a panel data analysis was used for the Brazilian states from 1981 to 1995. The panel structure offers important information gains due to joining time series and cross-section analysis in the same

\footnotetext{
${ }^{2}$ National Home Sampling Survey.

${ }^{3}$ Brazilian Geographic and Statistics Institute.

${ }^{4}$ National Treasury Secretary.

${ }^{5}$ Variation Inflation Factor.
} 
framework. The panel data analysis allows us to check for the existence of heterogeneity among the individual units (states). In this case, the importance of correlation problems regarding the omitted variable is much lower if compared with what happens when estimations are made based solely on time series or cross-section data (Hsiao, 2003). The results of the econometric model are presented in Table1.

First of all, like in Kelly (2000) all the included variables were transformed into logarithms. In this case, the coefficients obtained represent elasticities in relation to the variable of this coefficient. Secondly, the dependent variable, which in this case is the number of intentional homicides, is normalized in relation to the population. We also perform it for the variable Public Security. Third, it must be noted that the dependent variable, which is intentional homicide, as mentioned before, contains an observation error. However, we have assumed the hypothesis in which this error has a normal distribution with constant variation and mean zero. This makes the model fall under the usual hypotheses, and estimation is then easily made without bias (Greene, 1993).

In Table 3, the results are distributed in six columns. Columns (1)-(2) illustrate the estimation by simple regression OLS. The rest of them list the results estimated by panel data. Columns (3)-(4) and columns (5)-(6) present the estimates for the random effect and fixed effect, respectively. The need for a methodology that considers the heterocedastic nature existing among individuals is corroborated by the value of the parameter Rho, that indicates the proportion of the individual component's estimated variance in relation to the estimated variance of the disturbance. In all the panel data models in Table3, the value is greater than $80 \%$, indicating the importance of the individual component of the disturbance.

The Breusch-Pagan test that tests the null hypothesis in which the variance of the individual component is zero, reported in Table 3, indicates the rejection of the null hypothesis that the simple pooling specification is corrected. In this way, pooled OLS is biased and inconsistent. This result indicates that we must use panel data estimators and not the OLS estimators ${ }^{6}$. In Table 3 , the OLS estimation is shown for comparative analysis since the Breusch-Pagan test suggest that this estimation is biased and ineficient here. But, estimation by OLS allows us to identify whether there is multicolinearity in the model with the use of the $\mathrm{VIF}^{7}$ instrument that calculates the impact upon the variance of the one variable resulting from the correlations among the other regressors. The literature states that in order for an indication of multicolinearity to exist, the value that indicates the highest VIF should be greater than 5 (Judge et alli. 1982).

The Hausman test indicates that the hypothesis by which the individual effect is correlated with some explicative variable can not be rejected. Therefore, this result indicates that the estimation by random effect does not generate consistent estimators for the model. In this way, we should focus on the fixed effect results..

The results related to fixed effect in columns (5)-(6) indicates that unemployment level, income inequality and urbanization generate homicides. For poverty, the results are not robust, but we can state contrary to the conventional wisdom and disorganization theory that it does not have positive impact on criminality. In fact, if we take all the results related to this variable in Table3, it is almost impossible to find for the Brazilian case the existence of negative correlation between poverty and crime. This achievement is close to one appears in Kelly (2000) for violent crime. According to this author, most people in poverty are children, single mothers or elderlies. These groups have no comparative advantage to resort in criminality. We can note too that public security and schooling are not statistically significant in the determination of intentional homicides ${ }^{8}$.

\footnotetext{
${ }^{6}$ Wooldridge (2001) pp. 439-41 and Baltagi (1995) pp. 60-62.

${ }^{7}$ Variation Inflation Factor.

${ }^{8}$ The exclusion of these variables do not change qualitatively the results presented in Chart 1.
} 
Regarding the unemployment rate, it may be stated that the result obtained for the sign and value of the coefficient is in agreement with most of the studies appearing in the literature [Erlich, (1973), Trumbull, (1989), Wong, (1995), Gould, Wienberg and Mustard (1997)]. We can note that an increase of $10 \%$ in unemployment generates an increase of about $1.2 \%$ in the intentional homicides homicides. Fajnzylber and Araújo (2001), in a study also conducted for the Brazilian case, and Magalhães (1997), in a study of the Federal District (Brazil) using time series show that unemployment has a net positive effect on criminality. In the same way, an increase of $10 \%$ in the social inequality, represented by the Gini index, generates an increase obout $8.0 \%$ in the intentional homicides. This strong evidence suggests the importance of inequality on criminality for Brazil.

\section{TABLE 3}

Another point that needs to be stressed refers to the sharp difference between the results obtained for the Gini variable. In the all panel data models that consider the omitted individual effect, columns (3)-(6), we find a positive effect of inequality over premedited homicide. The opposite was found for the OLS estimator. This seems to be due to the fact that in the OLS regression the Gini index coefficient is biased, since specificities among individual units (states) are not considered. The consideration of these factors is extremely relevant because they may greatly alter the estimated coefficient of a variable. If a methodology that allows us to consider the differences among the individual units (states) is not incorporated into this study, we would have a completely distorted idea of how income inequality affects criminality. Confirming our initial intuition, income inequality represented by the Gini index has significant influence in explaining criminality.

In fact, Income is also poorly distributed within regions and states. There are five regions in Brazil, namely, North, Northeast, South, Southeast and Midwest. The poverty situation is worst in the Northeast where we find 38.2 percent of workers earning less than half of the minimum wage. In the North, 26 percent of workers fall within this category, while in the Midwest, South and Southeast the counterparts are 15.9, 13 and 10.8, respectively. The Southeast region is the most affluent in the country. It contains the states of São Paulo, Rio de Janeiro, Minas Gerais and Espírito Santo. In 1996-1997, 40 percent of São Paulo's population was below the poverty line. For Rio de Janeiro and Minas Gerais, for example, the percentages of the state population below the poverty line were 35 and 51, respectively.

One important question that emerges in Table 3 is about the sign's radical change of the variable public security comparing both the couple of comumns (3)-(5) and (4)-(6), and also in view the results generated by OLS. Indeed, fixed effect estimator is able to control endogeneity when it comes from the correlation existing between error's especific component and regressors (Mundlak, 1978). But in the case of public security, it is possible that the source of endogeneity is related to reverse causality we discussed at the end of Section 3 . To be more especific, here the source of endogeneity probably comes from not the correlation of this variable with error's individual component, but with the non specific component of disturb $^{9}$. In order to investigate this issue, we will aply a panel data base in the $\mathrm{GMM}^{10}$ metodology. Like last one it controls unobserved unity-specific effects too, but it also controls

\footnotetext{
${ }^{9}$ In the panel data model, the disturbance $u_{i t}$ is made up of two random components, the individual effect $\alpha_{i}$, and nom-specific disturb $\varepsilon_{i t}$, so that $u_{i t}=\alpha_{i}+\varepsilon_{i t}$ (Hsiao, 2003).

${ }^{10}$ Generalized Method of Moments
} 
the joint endogenity of the explanatory variables and some types of measurement errors in the dependent variable.

Our econometric model follows the methodology was first developed by Arellano and Bond (1991) and Arellano and Bover (1995). In fact, we base our estimatives on the so-called "system GMM"11 (Blundell and Bond, 1998) and not on the later version known as "difference GMM"12. These estimators instead of assuming strict exogeneity allow for the limited form of simultaneity and reverse causality. Specifically, we adopt the more flexible assumption of weak exogeneity, that is, current values of the explanatory variables may be affected by past and current realizations of dependent variable but not its future innovations. The results obtained by "system GMM" are showed in Table 4.

Due to the collinearity we discussed above we again present the estimates for two set of explanatory variables, but this time we introduced in each one the first lag of the dependent variable. The motivation behind the use of lag is its dynamic appeal. This appears in for columns (2) and (4) First of all, we must check if there is no specification problem. There are in Table 4 three specification tests. Firstly, the Sargan test reports a test of over-identifying restrictions, which test the null hypothesis of overall validity of the instruments. Failure to reject this hypothesis gives support to the model. We also have two test for autocorrelation for $\mathrm{AR}(1)$ and $\mathrm{AR}(2)$ autocorrelation. $\mathrm{AR}(1)$ is expected in first differences, but higher-order autocorrelation indicates that some lags of the dependent variable, which might be used as instruments, are in fact endogenous. We can see in Table4 that the results for these test suport our model.

The dynamic appeal is related to some kind of "inertial effect" on homicides. (Fajnzylber et al., 2000). We can see that the current homicide rate has effect in future values of this variable. The results in Table4 for colums (1)-(3) are similar to the fixed effect estimates for (5)-(6) in Table 4 but the coeficient of public security. In all regressions in Table4, the sign of this variable is negative, so in view of Sargan test' results we can state that the GMM system estimator has been able to control the endogeneity for public security. Then another achieviment of this study is that for the Brazilian case spending in public security is effective to control criminality.

\section{TABLE4}

\subsection{The Granger Causality Test for Income Inequality and Public Security.}

Considering the fundamental importance between inequality and crime in this study, our task now is to verify the consistency of this relation. In other words, we shall attempt to verify the correct causality relation between these variables. In last Section we verified the existence of statistical correlation between crime and inequality. But, as we had already stressed in Section 2 it is possible that criminality causes inequality. In order to check the true causality of this relation we will use for that the Granger causality approach (Granger, 1969).

In order to adapt the Granger Causality test to a panel data context, a representative procedure used to test causality in a panel appears in Holtz-Eakin et al. (1988). This model is expressed as follows

\footnotetext{
${ }^{11}$ A problem with the original Arellano-Bond estimator is that lagged levels are often poor instruments for first differences, especially for variables that are close to a random walk. Arellano and Bover (1995) described how, if the original equations in levels were added to the system, additional moment conditions could be brought to bear to increase efficiency. In these equations, predetermined and endogenous variables in levels are instrumented with suitable lags of their own first differences. Blundell and Bond (1998) articulates the necessary assumptions for this augmented estimator more precisely and tested it with Monte Carlo simulations (Bond, 2002).

${ }^{12}$ This estimator has low asymtotic precision and large biases in small samples Blundell and Bond (1997).
} 


$$
y_{i t}=\alpha_{0}+\sum_{j=1}^{m} \alpha_{j} y_{i t-j}+\sum_{j=1}^{n} \delta_{j} x_{i t-j}+f_{i}+u_{i t}
$$

where $i=1, \ldots, N$, represents the units, and $t=1, \ldots, m$, represents the time index.

Eliminating the fixed effect $f_{i}$, the model in differences assumes the following form

$$
y_{i t}-y_{i t-1}=\sum_{j=1}^{m} \alpha_{j}\left(y_{i t-j}-y_{i t-j-1)}+\sum_{j=1}^{m} \delta_{j}\left(x_{i t-j}-x_{i t-j-1}\right)+\left(u_{i t}-u_{i t-1}\right) .\right.
$$

Such a specification introduces a simultaneity problem due to the fact that the disturbance is correlated with $y_{i t-j}-y_{i t-j-1}$. In this case, a consistent alternative is estimating the model by using the two-stage instrumental variable method (2SLS). Once this is done, in order to verify whether $x$ causes $y$, we only need to test the joint hypothesis $\delta_{1}=\delta_{2}=\ldots=\delta_{m}=0$ (NairReicheit and Weinhold, 2001). We must keep in mind, however, that in order to maintain the consistency of the causality relation, we need to test the reverse causality, and see whether the joint hypothesis of $y$ causing $x$ is non-significant, because if it is not, then it would not be possible to state anything in this sense.

Introducing the issue into the current context, to verify whether social inequality expressed the Gini index causes crime, we must prove that $\delta_{1}=\delta_{2}=\ldots=\delta_{m}=0$ in the following model ${ }^{13}$

$$
\operatorname{mortp}_{i t}-\operatorname{mortp}_{i t-1}=\sum_{j=1}^{m} \alpha_{j}\left(\operatorname{mortp}_{i t-j}-\operatorname{mortp}_{i t-j}\right)+\sum_{j=1}^{m} \delta_{11}\left(\operatorname{gini}_{i t-j}-g i n i_{i t-j}\right)+u_{i t}-u_{i t-1}
$$

where mortp is the ratio between intentional homicides and the population. In order to estimate this model, we may use mortp $_{i t-2}$ or mortp $_{i t-2}-$ mortp $_{i t-3}$ as instruments (Hsiao, 1986). Table5 below presents the results of the Granger procedure to identify the consistency of the relation between income inequality, crime and public pecurity.

\section{TABLE 5}

The reason to perform Granger causality approach for public pecurity and crime is because in last section we found existence of endogeneity between these variables. In this way, if there is a bi-causality or reverse causality in this case, Granger causality test stress the identification problem between these variables, that is, we will stress it in more robust sense way. In Table5 there are four regressions in order to perform the Granger causality test. Due to short temporal dimension of the sample, we decide to include just three lags in the model. Considering the results from regression 1, the causality test shows that, in the Granger sense, inequality causes crime. In regression 2, however, causality is not observed in the reverse sense, showing that income inequality, as measured by the Gini index, causes criminality in Granger sense. In regression 3, we can verify that public security granger causes crime. Furthermore, regression 4, also shows that crime Granger causes public security. In this way,

\footnotetext{
${ }^{13}$ Mortp $=$ terminology for intentional homicide.
} 
there is a bi-causality relation between crime and public security. In other words, the Granger causality test confirms the identification problem between these variables.

This exercise help us to clariry about the true relation between inequality and criminality. Bourguinon (1998) argues that the "positive link between these variables in a cross-section countries may be due to unoberserved factors affecting simultaneously inequality and criminality rather than to some causal relationship between these variables". In view the results obtained by Granger causality test performed above we showed that the correlation between inequality and criminality is not spurious. Our results is in accord with Fajnzylber et al. (1999) and Soares (1999). Both studies concluded that relationship between these variables is robust in sense of finding a significant crime-inducing effect of income inequality.

\section{Conclusions.}

The objective of this study was to shed light on the main determinants of criminality in Brazil. In order to undertake it we performed an econometric model based in panel data analysis for Brazilian states. We focus our analysis on intentional homicide. One of the advantages of the panel data approach is that it allows the consideration of heterogeneity among the units what fits well with the country's immense income disparity existing in this country. Among the major conclusions of this research we have an important result that income inequality plays a major role in the determinantion of criminality.

The econometric results also showed that others variables like unemployment and urbanization are positively related to crime factors. An interesting achievement of the present work is related to its dynamic appeal. Based in panel data GMM methodology we found the existence of "inertial effect" on criminality. Panel data GMM estimator was also used to control the existence of endogeneity related to the variable public security. In this case, the resulted showed that public security spending is effective to diminish criminality. Contrary to the common wisdon, we cannot found evidence that poverty increases crime. In fact, the results, albeit not too robust, indicate that poverty and criminality based in intentional homicide are negative correlated.

Finally considering the results from the Granger causality tests, it was possible to show that inequality causes crime in fact and not the contrary, what supports that the income inequality in an inequivocous determinant of criminality. 


\section{References.}

Aghion, P. and P. Howitt. Endogenous Growth Theory. MIT Press, 1998.

Andrade, M. V. e Lisboa, M. B. Mortalidade nos Estados do Rio de Janeiro, São Paulo e Minas Gerais. Estudos Econômicos. São Paulo,31(1): 5-56, 2001.

Arellano, M. and S. Bond. Some tests of specification for panel data: Monte Carlo evidence and an application to employent equations. The Review of Economic Studies 58: 277-297, 1991.

Arellano, M. and O. Bover. Another look at the instrumental variable estimation of errorcomponents models. Journal of Econometrics, 68: 29-51, 1995.

Baltagi, B. H. Econometric Analysis of Panel Data. John Wiley \& Sons, 1995.

Becker, G. S. Crime and Punishment: An Economic Approach. Journal of Political Economy, 101: 169-217, 1968

University Press, 1975

Human Capital: a theoretical and empirical analisys. New York: Columbia

Bénabou, R. Inequality and Growth. NBER Macroeconomics Annual 11, 1996.

Blundell, R. and S. Bond. Initial conditions and moment restrictions in dynamic panel data models. Journal of Econometrics 87: 115-43, 1998.

Blumstein, A. Touth Violence, Guns and the Illicit-Drug Industry. The Journal of Criminal Law and Criminology, 86(4): 1175-1216, 1995.

Blumstein, A. and Rosenfeld, R. Explaining Recent Trends in U.S. Homicide Rates. The Journal of Criminal Law and Criminology, 86(1): 10-36, 1998.

Bond, S. Dynamic panel data models: A guide to micro data methods and practice. Working Paper 09/02. Institute for Fiscal Studies, London, 2002.

Bourguinon, F. Crime as a Social Cost of Poverty: A Review Focusing on Developing Countries. World Bank. 1999.

Cano, I. e Santos, N. Uma Comparação das Fontes de Informação sobre Violência Letal. Mímeo. ISER, 2000.

Card, D. Estimating the Return to Scooling: Progress on Some Persistent Econometric Problems. Econometrica, 69(5): 1127-1160, 2001.

Daly, Martin, Wilson, Margo and Shawn Vasdev. Income inequality and homicide rates in Canada and the United States, Canadian Journal of Criminology, April : 219-236, 2001.

Durlauf, N. S. A Framework for the Study of Individual Behavior and Social Interactions. Working Paper, University of Wisconsin at Madison, Department of Economics, 2001.

Ehrlich, I. Participation in Illegitimate Activies: A Theorical and Empirical Investigation. Journal of Political Economy, 81: 521-565, 1973.

Ehrlich, I. Deterrent Effect of Capital Punishment: A Question of Life and Death. American Economic Review, 65(3): 397-417, december, 1975.

Fajnzylber, P. e Araújo Jr., A. Violência e Criminalidade, em Microeconomia Aplicada no Brasil. Fundação Getúlio Vargas, 2001.

Fajnzylber, P., Lederman, D. and Loayza, N. What Causes Violent Crime. European Economic Review, 46: 1323-1357, 2000.

. Inequality and Violent Crime. World Bank. 1999.

Fleischer, B. M. The Effect of Income on Delinquency. American Economic Review, 56: 118137, 1966.

Freeman, R. B. Crime and Job Market. NBER Working Paper 4910, 1994.

Freeman, R. B. The Economics of Crime. Handbook of Labor Economis, v. 3, edited by O. Ashenfelter and D. Card, 1999.

Freeman, R. B. and Rodgers III, W. M. Area Economic Conditions and the Labor Market Outcomes of Young Men in the 1990s Expansion. NBER Working Paper 7073, April 1999. 
Glaeser, E. L.and Sacerdote, B. Why is There More Crime in Cities. Journal of Political Economy, 107(6): S225-S258, 1999.

Glaeser, E. L., Sacerdote, B. and Scheinkman, J. A. Crime and Social Interactions. Quaterly Journal of Economics, 111: 507-548, 1996.

Gould, Eric D., Weinberg, Bruce A., Mustard, David B. Crimes Rates and Local Market Opportunities in the United States: 1979-1997.

Granger, C. Investigating Causal Relations by Econometric Model and Cross-Spectral Methods. Econometrica, 37: 424-438, 1969.

Greene, W. Econometric Analisis. Prentice Hall, 1993.

Grogger, J. Local Violence and Educational Attainment. The Journal of Human Resources, 32(4): 659-682.

Hagan, J. and Petersen, R. D. Crime and Inequality. Stanford University Press, 1995.

Kennedy, B., Kawachi, I., Prothrow-Stith, D., Lochner, K. and R. V. Gupta. Social Capital, Income Inequality, and Firearm Violent Crime. Social Science and Medicine 47(1): 7-17, 1998.

Holtz-Eakin, D., Newey, W. and Rosen, H. Estimating Vector Autoregressions with Panel Data,. Econometrica, 56(6): 1371-1395, 1988.

Hsiao, C. Analysis of Panel Data. Cambridge University Press, 2003.

Imai, S. and Krishna, K. Employment, Dynamic Deterrence and Crime. NBER Working Paper 8281, 2001.

Judge, G., Hill, C.W. Griffiths, C. W., Lee, T. and Lutkepol, H. Introduction to the Theory and Practice of Econometrics. New York: Wiley, 1985.

Kelly, M. Inequality and Crime. The Review of Economic and Statistic. 82(4): 530-539.

Lochner, S. D. A Theorical and Empirical Study of Individual Perceptions of the Criminal Justice System. NBER Working PaperSeries, 2001.

Levitt, S. D. The Effect of Prison Population Size on Crime Rates: Evidence from Prison Overcrowding Litigation. Quaterly Journal of Economics, 111: 320-351, 1996.

Levitt, S. D. and Venkatesh, S. A. An Economic Analisis of Drug-Selling Gangs's Finances. National Bureau of Economic Research Working Paper, 1998.

MacDonald, Ziggy (2002) Official Crime Statistics: Their Use and Interpretation. The Economic Journal, 112: F85-F106.

Magalhães, T. A. Desemprego e Crime - uma análise de séries temporais para o Distrito Federal: 1992-1996. Master Thesis, UNB, Department of Economics, 1997.

Mendonça, M. J. C., Loureiro, P. R. A., Sachsida, A Interação Social e Crimes Violentos: uma análise empírica a partir do Presídio de Papuda. Estudos Econômicos, 32(4): 621-641, 2002.

Merton, R. Social Structure and Anatomie. American Sociological Review, 3: 672-682, 1938.

Mincer, J. Investment in Human Capital and Personal Income Distribution. Journal of Political Economy, .66(4): 281-302, 1958.

Pearsson T. and Tabellini, G. Is Inequality Harmful for Growth? Theory and Evidence. American Economic Review, 48: 600-621.

Nair-Reicheit, U. and Weinhold, D.. Causality Tests for Cross-Country Panels: New Look at FDI and Economic Growth in Developing Countries. Oxford Bulletin of Economics and Statistics, 63(2): 151-171, 2001.

Soares, J. B. Development, Crime and Punishment: Accounting for the International Differences in Crime Rates. Mimeo. Department of Economics. University of Chicago.

Trumbull, W. N. Estimating of the economic model of crime using aggregate and individual data level. Southern Economic Journal, v. 56, p. 423-439, 1989.

Witte, A. D. and Witt, R. What we Spend and What We Get: Public and Provision of Crime Prevention and Criminal Justice. NBER Working Paper n. 8204, 2001. 
Wooldridge, F. M. Econometric Analysis of Cross-Section and Panel Data. MIT Press, 2001.

\section{TABLES}

Table 1.

Explanatory Variables for Intentional Homicides (Crimes)

\begin{tabular}{|l|l|l|}
\hline \multicolumn{1}{|c|}{$\begin{array}{c}\text { Explanatory Variables } \\
\text { (1) }\end{array}$} & \multicolumn{1}{|c|}{$\begin{array}{c}\text { Terminology } \\
\text { (2) }\end{array}$} & \multicolumn{1}{c|}{$\begin{array}{c}\text { Expected sign } \\
\text { (3) }\end{array}$} \\
\hline Average family income & Income & Positive/Negative \\
\hline Law enforcement spending & Public Security & Negative \\
\hline Rate of urbanization & Urbanization & Positive \\
\hline Gini index & Gini & Positive \\
\hline Rate of unemployment & Unemployment & Positive/Negative \\
\hline Schooling & Schooling & Positive/Negative \\
\hline
\end{tabular}

Table 2.

Correlations Among Explanatory Variables (Pooling Data: 1981-1995).

\begin{tabular}{c|ccccccc}
\hline & Income & Schooling & Poverty & Gini & $\begin{array}{c}\text { Public } \\
\text { Security }\end{array}$ & $\begin{array}{c}\text { Unemploy } \\
\text { ment }\end{array}$ & Urbanization \\
\hline Income & 1.000 & & & & & & \\
Schooling & 0.8559 & 1.000 & & & & & \\
Poverty & -0.8642 & -0.6920 & 1.000 & & & & \\
Gini & -0.1959 & -0.2116 & 0.4075 & 1.000 & & & \\
Public & 0.3603 & 0.2565 & -0.2600 & 0.3256 & 1.000 & & \\
$\begin{array}{c}\text { Security } \\
\text { Unemploy } \\
\text { ment }\end{array}$ & 0.0768 & 0.3148 & 0.1539 & 0.1100 & 0.1443 & 1.000 & \\
\begin{tabular}{c} 
Urbanization \\
\hline
\end{tabular} & 0.6610 & 0.6640 & -0.4778 & 0.1122 & 0.5160 & 0.3487 & 1.000 \\
\hline
\end{tabular}


Table 3.

Econometric Model for Intentional Homicide*

\begin{tabular}{|c|c|c|c|c|c|c|}
\hline $\begin{array}{c}\text { Independent } \\
\text { Variables }\end{array}$ & $\begin{array}{l}\text { OLS } \\
(1)\end{array}$ & $\begin{array}{l}\text { OLS } \\
(2)\end{array}$ & $\begin{array}{l}\text { RE } \\
\text { (3) }\end{array}$ & $\begin{array}{l}\text { RE } \\
(4)\end{array}$ & $\begin{array}{l}\text { FE } \\
(5)\end{array}$ & $\begin{array}{l}\text { FE } \\
(6)\end{array}$ \\
\hline Poverty & $\begin{array}{c}-0.032 \\
(0.804)\end{array}$ & $\begin{array}{c}-0.208 \\
(0.049)\end{array}$ & $\begin{array}{c}-0.112 \\
(0.106)\end{array}$ & $\begin{array}{l}-0.155 \\
(0.021)\end{array}$ & $\begin{array}{c}-0.089 \\
(0.114)\end{array}$ & $\begin{array}{l}-0.107 \\
(0.090)\end{array}$ \\
\hline Gini & $\begin{array}{c}-2.012 \\
(0.001)\end{array}$ & $\begin{array}{l}-1.989 \\
(0.001)\end{array}$ & $\begin{array}{c}0.634 \\
(0.005)\end{array}$ & $\begin{array}{c}0.781 \\
(0.003)\end{array}$ & $\begin{array}{c}0.718 \\
(0.008)\end{array}$ & $\begin{array}{c}0.801 \\
(0.026)\end{array}$ \\
\hline Urbanization & $\begin{array}{c}1.683 \\
(0.000)\end{array}$ & $\begin{array}{c}1.911 \\
(0.000)\end{array}$ & $\begin{array}{c}0.807 \\
(0.058)\end{array}$ & $\begin{array}{c}1.401 \\
(0.000)\end{array}$ & $\begin{array}{c}0.793 \\
(0.088)\end{array}$ & $\begin{array}{c}1.150 \\
(0.001)\end{array}$ \\
\hline Unemployment & $\begin{array}{c}0.279 \\
(0.004)\end{array}$ & $\begin{array}{c}0.374 \\
(0.000)\end{array}$ & $\begin{array}{c}0.122 \\
(0.012)\end{array}$ & $\begin{array}{c}0.142 \\
(0.003)\end{array}$ & $\begin{array}{c}0.120 \\
(0.012)\end{array}$ & $\begin{array}{c}0.129 \\
(0.007)\end{array}$ \\
\hline Public Security & $\begin{array}{c}-0.268 \\
(0.000)\end{array}$ & $\begin{array}{c}-0.281 \\
(0.000)\end{array}$ & $\begin{array}{c}-0.027 \\
(0.605)\end{array}$ & $\begin{array}{l}-0.024 \\
(0.647)\end{array}$ & $\begin{array}{c}0.073 \\
(0.214)\end{array}$ & $\begin{array}{c}0.083 \\
(0.152)\end{array}$ \\
\hline SchoolMale15 & $\begin{array}{c}0.469 \\
(0.000) \\
\end{array}$ & - & $\begin{array}{c}0.512 \\
(0.031)\end{array}$ & - & $\begin{array}{c}0.303 \\
(0.242) \\
\end{array}$ & - \\
\hline Constant & $\begin{array}{c}-9.642 \\
(0.000)\end{array}$ & $\begin{array}{r}-10.020 \\
(0.000)\end{array}$ & $\begin{array}{c}-7.724 \\
(0.000)\end{array}$ & $\begin{array}{c}-9.502 \\
(0.000)\end{array}$ & $\begin{array}{l}-8.719 \\
(0.000)\end{array}$ & $\begin{array}{c}-9.904 \\
(0.000)\end{array}$ \\
\hline VIF & 2.451 & 1.830 & - & - & - & - \\
\hline $\mathbf{R}^{2}$ & 0.401 & 0.390 & 0.200 & 0.139 & 0.246 & 0.242 \\
\hline Rho & - & - & 0.822 & 0.814 & 0.846 & 0.878 \\
\hline $\begin{array}{c}\text { Hausman } \\
\text { Test }\end{array}$ & - & - & $\begin{array}{c}15.73 \\
(0.010)\end{array}$ & $\begin{array}{c}20.11 \\
(0.000)\end{array}$ & - & - \\
\hline $\begin{array}{c}\text { Breusch-Pagan } \\
\text { Test } \\
\end{array}$ & - & - & $\begin{array}{l}833.34 \\
(0.000) \\
\end{array}$ & $\begin{array}{l}843.33 \\
(0.000) \\
\end{array}$ & - & - \\
\hline Observations & 319 & 319 & 319 & 319 & 319 & 319 \\
\hline
\end{tabular}

*: the values in parentheses are the p-values of the variables. 
Table 4.

Econometric Model for Intentional Homicide: Panel Data GMM System Estimator*

\begin{tabular}{|c|c|c|c|c|}
\hline $\begin{array}{c}\text { Independent } \\
\text { Variables }\end{array}$ & (1) & (2) & (3) & (4) \\
\hline Mortp_1 ${ }^{* *}$ & - & $\begin{array}{c}0.617 \\
(0,000)\end{array}$ & - & $\begin{array}{c}0.932 \\
(0,000)\end{array}$ \\
\hline Poverty & $\begin{array}{l}-0.235 \\
(0.022)\end{array}$ & $\begin{array}{l}-0.127 \\
(0.058)\end{array}$ & $\begin{array}{l}-0.620 \\
(0.000)\end{array}$ & $\begin{array}{l}-0.154 \\
(0.007)\end{array}$ \\
\hline Gini & $\begin{array}{c}0.803 \\
(0.003)\end{array}$ & $\begin{array}{c}0.667 \\
(0.012)\end{array}$ & $\begin{array}{c}0.672 \\
(0.000)\end{array}$ & $\begin{array}{c}0.780 \\
(0.024)\end{array}$ \\
\hline Urbanization & $\begin{array}{c}0.860 \\
(0,064)\end{array}$ & $\begin{array}{c}0.787 \\
(0.056)\end{array}$ & $\begin{array}{c}0.720 \\
(0,000)\end{array}$ & $\begin{array}{c}0.408 \\
(0.101)\end{array}$ \\
\hline Unemployment & $\begin{array}{c}0.202 \\
(0.097)\end{array}$ & $\begin{array}{c}0.071 \\
(0.109)\end{array}$ & $\begin{array}{c}0.364 \\
(0.000)\end{array}$ & $\begin{array}{c}0.050 \\
(0.050)\end{array}$ \\
\hline Public Security & $\begin{array}{l}-0.322 \\
(0,064)\end{array}$ & $\begin{array}{l}-0,078 \\
(0,000)\end{array}$ & $\begin{array}{l}-0.373 \\
(0,000)\end{array}$ & $\begin{array}{l}-0,048) \\
(0,059)\end{array}$ \\
\hline SchoolMale15 & $\begin{array}{c}0.948 \\
(0.002)\end{array}$ & $\begin{array}{c}0.071 \\
(0.006)\end{array}$ & - & - \\
\hline Constant & $\begin{array}{c}-4.561 \\
(0.0080)\end{array}$ & $\begin{array}{l}1.473 \\
(0.001)\end{array}$ & $\begin{array}{c}5.586 \\
(0.000)\end{array}$ & $\begin{array}{l}1.007 \\
(0.007)\end{array}$ \\
\hline $\begin{array}{c}\text { Serial Correlation } \\
\text { AR(1) }\end{array}$ & $\begin{array}{l}-1.300 \\
(0.002)\end{array}$ & $\begin{array}{l}-3.100 \\
(0.002)\end{array}$ & $\begin{array}{l}-1.300 \\
(0.002)\end{array}$ & $\begin{array}{l}-4.640 \\
(0.002)\end{array}$ \\
\hline $\begin{array}{c}\text { Serial Correlation } \\
\operatorname{AR}(2)\end{array}$ & $\begin{array}{c}0.062 \\
(0.952)\end{array}$ & $\begin{array}{c}0.300 \\
(0.765)\end{array}$ & $\begin{array}{c}0.005 \\
(0.982)\end{array}$ & $\begin{array}{l}-0.180 \\
(0.858)\end{array}$ \\
\hline Sargan Test & $\begin{array}{c}91.71 \\
(0.992)\end{array}$ & $\begin{array}{l}121.90 \\
(0.587)\end{array}$ & $\begin{array}{c}97.52 \\
(0.982)\end{array}$ & $\begin{array}{l}143.09 \\
(0.459)\end{array}$ \\
\hline Observations & 309 & 263 & 309 & 263 \\
\hline
\end{tabular}

The values in parentheses are the p-values of the variables. ${ }^{* *}$ Mortp $=$ terminology for intentional homicide, Mortp_1 = First lag of Mortp. 
Table 5.

Granger Causality Test*.

\begin{tabular}{|c|c|c|c|}
\hline \multicolumn{2}{|c|}{$\begin{array}{c}\text { Regression } 1 \\
\text { Dependent variable }=\text { Dmortp }^{1}\end{array}$} & \multicolumn{2}{|c|}{$\begin{array}{c}\text { Regression } 2 \\
\text { Dependent variable }=\text { Dgini }\end{array}$} \\
\hline Dmortp_1 $1^{2}$ & $\begin{array}{r}-0.0671 \\
(0.346)\end{array}$ & Dgini_1 & $\begin{array}{r}-0.5055 \\
(0.000)\end{array}$ \\
\hline Dmortp_2 & $\begin{array}{l}-0.0522 \\
(0.477)\end{array}$ & Dgini_2 & $\begin{array}{l}-0.2750 \\
(0.008)\end{array}$ \\
\hline Dmortp_3 & $\begin{array}{l}-0.1636 \\
(0.030)\end{array}$ & Dgini_3 & $\begin{array}{r}-0.3335 \\
(0.001)\end{array}$ \\
\hline Dgini_1 & $\begin{array}{l}0.5824 \\
(0.061)\end{array}$ & Dmortp_1 & $\begin{array}{l}-0.0050 \\
(0.801)\end{array}$ \\
\hline Dgini_2 & $\begin{array}{l}-0.2067 \\
(0.574)\end{array}$ & Dmortp_2 & $\begin{array}{l}0.0275 \\
(0.185)\end{array}$ \\
\hline Dgini_3 & $\begin{array}{l}-0.4670 \\
(0.183)\end{array}$ & Dmortp_3 & $\begin{array}{l}0.0016 \\
(0.940)\end{array}$ \\
\hline Causality test & 7.08 & Causality test & 2.02 \\
\hline$\delta_{1}=\delta_{2}=\delta_{3}=0$ & $(0.069)$ & $\delta_{1}=\delta_{2}=\delta_{3}=0$ & $(0.569)$ \\
\hline Observations & 189 & Observations & 189 \\
\hline \multicolumn{2}{|c|}{$\begin{array}{c}\text { Regression } 3 \\
\text { Dependent variable }=\text { Dmortp }^{1}\end{array}$} & \multicolumn{2}{|c|}{$\begin{array}{c}\text { Regression } 4 \\
\text { Dependent variable }=\text { Dpublicsecurity }\end{array}$} \\
\hline Dmortp_1 ${ }^{2}$ & $\begin{array}{l}0.0265 \\
(0.706)\end{array}$ & Dpublicsecurity_1 & $\begin{array}{l}-0.5643 \\
(0.000)\end{array}$ \\
\hline Dmortp_2 & $\begin{array}{l}-0.0998 \\
(0.148)\end{array}$ & Dpublicsecurity_2 & $\begin{array}{l}-0.4601 \\
(0.000)\end{array}$ \\
\hline Dmortp_3 & $\begin{array}{l}-0.1311 \\
(0.070)\end{array}$ & Dpublicsecurity_3 & $\begin{array}{l}-0.2676 \\
(0.020)\end{array}$ \\
\hline Dpublicsecurity_1 & $\begin{array}{l}-0.1838 \\
(0.002)\end{array}$ & Dmortp_1 & $\begin{array}{c}-0.0243 \\
(0.820)\end{array}$ \\
\hline Dpublicsecurity_2 & $\begin{array}{l}-0.0101 \\
(0.880)\end{array}$ & Dmortp_2 & $\begin{array}{l}0.1351 \\
(0.199)\end{array}$ \\
\hline Dpublicsecurity_3 & $\begin{array}{l}0.0816 \\
(0.279)\end{array}$ & Dmortp_3 & $\begin{array}{l}-0.3452 \\
(0.002)\end{array}$ \\
\hline $\begin{array}{c}\text { Causality test } \\
\delta_{1}=\delta_{2}=\delta_{3}=0\end{array}$ & $\begin{array}{c}14.22 \\
(0.002)\end{array}$ & $\begin{array}{c}\text { Causality test } \\
\delta_{1}=\delta_{2}=\delta_{3}=0\end{array}$ & $\begin{array}{c}12.66 \\
(0.005)\end{array}$ \\
\hline Observations & 189 & Observations & 189 \\
\hline
\end{tabular}

*: the values in parentheses are the p-values. ${ }^{1}$ Dmortp=mortp-mortp(-1), ${ }^{2}$ Dmortp_1=mortp(-1)-mortp(-2), Dmortp_2 $=$ mortp(-2) $-\operatorname{mortp}(-3)$. 